\title{
EFFECT OF DIFFERENT IRRIGATION INTERVALS, COMPOST AND BACTERIAL INOCULATION ON SESAME PRODUCTITY IN SANDY SOILS \\ Ismail, F. M. ${ }^{*}$; F. Sh. F. Badawi ${ }^{* *}$ and Fadia H. A. Ahmed ${ }^{*}$ \\ * Oil Crops, Field Crops Res. Inst., Agric. Res. Center (ARC), Giza, Egypt. \\ ** Agric Microbiol. Res. Dept., Soils, Water and Environ. Res. Inst., Agric. Res. Center, Giza, Egypt.
}

\begin{abstract}
Two field experiment were carried out at Ismailia Agricultural Research Farm Station located at $30^{\circ} 3^{\prime} 41.901^{\prime \prime} \mathrm{N}$ for Latitude and $32^{\circ} 16^{\prime} 45.834^{\prime \prime} \mathrm{E}$ for Longitude, Egypt, during two successive summer seasons of 2011 and 2012 to investigate the effect of irrigation water intervals (6, 9 and 12 days), compost rates ( 0 , 5 and 7 ton/fed) and bacterial inoculation (mixture of Serratia sp., B. polymyxa and Ps. fluorescens) on sesame productivity "variety Shandaweel 3" grown in sandy soil using sprinkler irrigation system. The experiments were laid out in a split-split plot design with three irrigation intervals as main plots and the three compost rates as sub-plots, while inoculation treatments randomly allotted in sub-sub plots.

All sesame yield and its attributes was highly significant affected by the duration of irrigation intervals and there was an inverse relationship between increasing the length of irrigation intervals and the studied yield characters. Irrigation at 6 day interval produced the highest values of sesame yield and yield attributes compared to other water regimes. Also, data exerted that the rate of promotion in the studied sesame yield and its attributes increased gradually as the rate of compost manuring increased. Sesame yield achieved the highest productivity as a result of soil manuring with 7 ton compost/fed followed by 5 ton compost/fed. On the other hand, inoculation with mixture of tested rhizobacteria exerted a salient superiority in values of sesame yield and its attributes relative to uninoculated treatment. The interaction effect among irrigation water intervals, compost rates and bacterial inoculation were significant on all estimated traits, except, plant height, height of first capsule, 1000seed weight and oil\%. Furthermore, oil yield/fed was positively and highly correlated with all estimated traits.

As a results of this study indicated that obtaining the highest sesame seed and oil yields/fed occurred when the crop was irrigated interval as narrow as possible up to 6 days interval along with inclusion of 7 ton compost/fed and rhizobacterial inoculation.

Keywords: Sesamum indicum L., Irrigation intervals, Compost, Plant growth promoting rhizobacteria (PGPR), Yield and Yield attributes.
\end{abstract}

\section{INTRODUCTION}

Sesame (Sesamum indicum L.) is an important oilseed crop in Egypt as well as in many parts of the world with great commercial attributes by virtue of its oil having an edible quality and medicinal value. It yields $50-60 \%$ oil and 35 to $50 \%$ protein and the oil is highly stable against rancidity due to the presence of the natural antioxidants sesamin and sesamolin (Boydak et al., 2007 and Sabah El-Khier et al., 2008). It provides mono-unsaturated fatty 
acid (oleic acid) and polyunsaturated fatty acid (linoleic acid). It is used in pharmaceutical and cosmetic industries and health food (Pornparn et al., 2009).

Irrigation management is very important in sesame crop, due to the shortage in water resources as well as expansion of agriculture in the newly reclaimed land. Adding much more or much less water causes serious crop damages. Therefore, it is necessary to determine the optimum water requirement and planning the best irrigation schedule for maximum crop production. Mathew and Kunju (1993) concluded that seed yield of sesame increased by increasing the number of irrigations. Kassab and Ibrahim (2005) and EI-Mahdi and El-Amin (2008) indicated that the very narrow irrigation intervals of six days increased seed yield in Egypt, hot desert conditions. Meanwhile, Boydak et al. (2007) reported that increasing the intervals between irrigations lowered the height of first capsule. Karaaslan et al. (2007) showed that extending the irrigation interval from 6 to 18 and 24 days decreased sesame yield from 1790 to 1550 and $1130 \mathrm{~kg} / \mathrm{ha}$, respectively.

Organic farming is an alternative agriculture providing quality and safe products and environment as synthetic chemical fertilizers and pesticides are not allowed. Application of mature compost to soil favors plant development and improves soil quality as well as having a suppressive effect on many diseases caused by soil borne plant pathogens (Cotxarrera et al., 2002). Moreover, compost amendments maintain and enhance the fertility and productivity of agricultural soils, allowing a sustainable land use (AbdelWahab et al., 2005 and Piqueres et al., 2006). In this concern, Gosling et al. (2006) and El-Saiid (2011) confirmed that the disintegration of the organic fertilizers in soil is very important to achieve the important roles of its activity. It can modify soil physical properties and strongly affects its chemical and biological ones.

Beneficial soil microorganisms play a salient role in construction of sustainable soil fertility via their responsibility for the vital biological processes. It is now recognized that soil bacteria called plant growth promoting rhizobacteria (PGPR) can promote the plant growth by individual or multiple physiological or nutritional mechanisms (Mantelin and Touraine, 2004). The mechanism by which these rhizobacteria enhance plant growth is postulated as direct and indirect mechanisms. The direct mechanisms include the provision of bio-available phosphorus for plant uptake, nitrogen fixation for plant use, sequestration of iron for plants by siderophores, production of phytohormones and modifying of plant ethylene levels (Kloepper, 2003). Indirect mechanisms used by PGPR comprise antibiotics production against pathogenic organisms, reduction of iron availability to phytopathogens in rhizosphere, synthesis of fungal cell lytic enzymes, inducing of systematic resistance and competition with detrimental microorganisms for sites on plant root (Van-Loon and Bakker, 2003). Numerous publications are indicating the importance of rhizobacterial inoculation to enhance plant growth and its productivity (Ghosh and Mohiuddin, 2000; Hewedy et al., 2008; Pornparn et al., 2009 and Badawi et al., 2011).

Therefore, the current study is carried out to study the effect of 
compost levels and bacterial inoculation at different irrigation intervals on yield and yield components of sesame grown under sandy soil conditions.

\section{MATERIAIS AND METHODS}

\section{Microorganisms and inoculants preparations:}

Serratia sp., Bacillus polymyxa (local isolates) and Pseudomonas fluorescens strain (IFO.2034) used as plant growth promoting rhizobacteria (PGPR) were supplied by Agric. Microbiol. Res. Depart., Soils, Water Res. Inst. (SWERI), ARC, Giza, Egypt. Serratia, Bacillus and Pseudomonas were grown in King's medium B (Atlas, 1995). Cultures were incubated at $28^{\circ} \mathrm{C}$ for three days on a rotary shaker until early log phase had been developed to $10^{9}$ viable cells $\mathrm{ml}^{-1}$, and then the cultures were transferred to sterile carrier materials.

To prepare inoculants of rhizobacteria, vermiculite supplemented with $10 \%$ Irish peat was packed in polyethylene bags $(400 \mathrm{~g} / \mathrm{bag})$, then sealed and sterilized by gamma irradiation $\left(5 \times 10^{6}\right.$ rads). Bacterial culture from each kind was injected into sterilized carrier to satisfy $60 \%$ of their maximal water holding capacity $\left(10^{7}\right.$ cells $/ g$ carrier).

Compost used:

Organic fertilizer (compost) was kindly supplied by SWERI, ARC, Giza, Egypt. Physico-chemical and biological traits of the used compost are shown in Table (1).

\section{Table (1): The main traits of used compost}

\begin{tabular}{|l|c|}
\hline \multicolumn{1}{|c|}{ Property } & Value \\
\hline Bulk density $\left(\mathrm{kg} / \mathrm{m}^{3}\right)$ & 558.0 \\
Water holding capacity (\%) & 196.5 \\
pH (1:10 extract) & 7.10 \\
EC (dS/m) & 3.50 \\
O-Carbon \% & 25.82 \\
T-Nitrogen \% & 1.57 \\
C/N ratio & 16.45 \\
Total-Phosphorus (\%) & 1.22 \\
Total-Potassium (\%) & 1.50 \\
Total soluble-N $\left(\mathrm{mg} \mathrm{kg}^{-1}\right)$ & 760.2 \\
Available-P $\left(\mathrm{mg} \mathrm{kg}^{-1}\right)$ & 292.5 \\
Available-K (mg kg $\left.{ }^{-1}\right)$ & 756.2 \\
DTPA-extractable (mg kg $\left.{ }^{-1}\right):$ & 212.6 \\
Fe & 48.3 \\
Mn & 51.3 \\
Zn & 7.6 \\
Cu & 122.5 \\
CEC (c mol/kg) & $12 \times 10^{7}$ \\
Total count of bacteria (cfu/g) & $11 \times 10^{6}$ \\
Total count of fungi (cfu/g) & $2.2 \times 10^{6}$ \\
Total count of actinomycetes (cfu/g) & 186.5 \\
Dehydrogenase activity (mg TPF/100 g) & 87.0 \\
Germination test of cress seeds (\%) &
\end{tabular}


Seeds:

Local sesame cultivar "Shandaweel 3" was provided by the Oil Crops Res. Dept., Field Crops Res. Inst., ARC, Giza, Egypt.

Field experiments:

Two field experiment were carried out at Ismailia Agricultural Research Station during two successive summer seasons of 2011 and 2012 to investigate the effect of different water intervals (6, 9 and 12 days), compost rates $(0,5$ and 7 ton/fed) and bacterial inoculation (mixture of Serratia sp., Bacillus polymyxa and Pseudomonas fluorescens) on sesame yield and its attributes grown under sandy soil conditions using sprinkler irrigation system. The physical and chemical analyses of the experimental soil are shown in Table (2).

Table (2):Physical and chemical properties of the experimental soil in both studied seasons

\begin{tabular}{|c|c|c|}
\hline \multirow{2}{*}{\multicolumn{3}{|c|}{\begin{tabular}{|l} 
Property \\
Particle size distribution (\%):
\end{tabular}}} \\
\hline & & \\
\hline Sand & 90.0 & 90.1 \\
\hline Silt & 3.8 & 3.7 \\
\hline Clay & 6.2 & 6.2 \\
\hline Texture grade & Sandy & Sandy \\
\hline $\mathrm{CaCO}_{3}$ & 1.64 & 1.62 \\
\hline Saturation percent (S.P \%) & 20.12 & 21.00 \\
\hline $\mathrm{pH}$ (soil paste) & 7.45 & 7.38 \\
\hline E.C $\left(\mathrm{dS} \mathrm{m}^{-1}\right.$, at $\left.25^{\circ} \mathrm{C}\right)$ & 0.32 & 0.30 \\
\hline \multicolumn{3}{|l|}{ Soluble cations and anions (meg L $\mathrm{L}^{-1}$ ): } \\
\hline $\mathrm{Ca}^{++}$ & 0.54 & 0.56 \\
\hline $\mathrm{Mg}^{++}$ & 0.33 & 0.30 \\
\hline $\mathrm{Na}^{+}$ & 1.62 & 1.53 \\
\hline $\mathrm{K}^{+}$ & 0.65 & 0.60 \\
\hline $\mathrm{CO}_{3}$ & 0.00 & 0.00 \\
\hline $\mathrm{HCO}_{3}^{-}$ & 0.88 & 0.84 \\
\hline $\mathrm{Cl}^{-}$ & 0.59 & 0.60 \\
\hline $\mathrm{SO}_{4}{ }_{4}$ & 1.67 & 1.55 \\
\hline Organic matter & 0.24 & 0.26 \\
\hline Organic-C & 0.14 & 0.15 \\
\hline Total-N & 0.020 & 0.022 \\
\hline $\mathrm{C} / \mathrm{N}$ ratio & 7.00 & 6.82 \\
\hline Total soluble- $\mathrm{N} \quad\left(\mathrm{mg} \mathrm{kg}^{-1}\right)$ & 17.30 & 16.30 \\
\hline Available- $\mathrm{P} \quad\left(\mathrm{mg} \mathrm{kg}_{-1}^{-1}\right)$ & 6.57 & 6.76 \\
\hline Available-K & 41.42 & 48.12 \\
\hline \multicolumn{3}{|l|}{ DTPA-extractable $\left(\mathrm{mg} \mathrm{kg}^{-1}\right)$ : } \\
\hline $\mathrm{Fe}$ & 1.31 & 1.21 \\
\hline $\mathrm{Mn}$ & 0.30 & 0.32 \\
\hline $\mathrm{Zn}$ & 0.46 & 0.48 \\
\hline $\mathrm{Cu}$ & 0.26 & 0.22 \\
\hline
\end{tabular}

DTPA: Di-ethylene tri-amine penta acetic acid.

The experiments were laid out in a split-split plot design with three replicates for each treatment. In main plots the three water intervals $(6,9$ and 
12 days) were randomly distributed, while the three compost rates $(0,5$ and 7 ton/fed) were randomly in sub-plots and the two bacterial inoculation treatments (uninoculated and inoculated with tested PGPR) were randomly allotted in sub-sub plots. The area of each sub-sub plot was $7.5 \mathrm{~m}^{2}(3 \times 2.5 \mathrm{~m})$ and consisted of five rows of $3 \mathrm{~m}$ long and $50 \mathrm{~cm}$ apart, while, hill spacing was $10 \mathrm{~cm}$. The preceding winter crop was wheat in both seasons.

All tested compost rates $(0,5$ and 7 ton/fed), superphosphate $(15.5 \%$ $\left.\mathrm{P}_{2} \mathrm{O}_{5}\right)$ at a rate of $200 \mathrm{~kg} / \mathrm{fed}$ and potassium sulphate $\left(48 \% \mathrm{~K}_{2} \mathrm{O}\right)$ at a rate of $50 \mathrm{~kg} / \mathrm{fed}$ were incorporated into soil 10 days before sowing. Sesame seeds were inoculated with gamma irradiated vermiculite-based inocula for each bacteria used at a rate of $400 \mathrm{~g}$ inoculum $/ 4 \mathrm{~kg}$ seeds, prior to sowing using $16 \%$ Arabic gum solution as an adhesive agent, then the inoculants were added and thoroughly mixed. Seeds of sesame were sown on 14 and 10 of May in 2011 and 2012, respectively. The growing sesame plants were thinned to specify the plant density and the crop was kept clean by hand weeding two and three weeks after sowing. All treatments received ammonium sulphate $(20.5 \% \mathrm{~N})$ at a rate of $40 \mathrm{~kg} \mathrm{~N} / \mathrm{fed}$, which added in two equal split doses after 15 and 30 days from sowing.

At harvest, the following characters were recorded on random samples of 10 guarded plants in each plot: plant height $(\mathrm{cm})$, height of first capsule $(\mathrm{cm})$, fruiting zone length $(\mathrm{cm})$, number of capsules/plant, 1000-seed weight $(\mathrm{g})$, and seed yield/plant $(\mathrm{g})$. In addition, seed yield $(\mathrm{kg} / \mathrm{fed})$ was determined based on the sub-sub plot data. Oil percentage was determined using Soxhlits apparatus according to the methods described by A.O.A.C (1980). Oil yield kg/fed was calculated by multiplying oil \% by seed yield.

Soil physical and chemical analysis and physico-chemical, and biological analyses of the used compost were carried out according to Jackson (1973) and Page et al. (1982).

Data were statistically analyzed separately for each season. Bartlet test of variance homogeneity was carried out before the combined analysis of both tested seasons according to Snedecor and Cochran (1980). Analysis of variance for all traits was made according to Gomez and Gomez (1984). Means were compared using L.S.D at $5 \%$ level. The simple correlation coefficients were determined between oil yield/fed and its attributes according to Svab (1973).

\section{RESULTS AND DISCUSSION}

1. Effect of irrigation intervals, compost and bacterial inoculation on plant height, height of first capsule and fruiting zone length of sesame plants:

a. Effect of irrigation intervals:

Data in Table (3) indicate that the plant height, height of first capsule and fruiting zone length was highly significant affected by the duration of irrigation intervals in both seasons and their combination. However, there was 
an inverse relationship between increasing the length of irrigation intervals and the studied yield attributes. Irrigation sesame plant at 6 day interval produced the tallest plants $(133.1 \mathrm{~cm})$, height of first capsule $(60.3 \mathrm{~cm})$ and the highest fruiting zone length $(72.9 \mathrm{~cm})$ compared to the other tested water regimes. This trend may be due to that water deficit during the vegetative period affected negatively all growth and yield parameters as well as some metabolic activities. These results are in consistent with those of Kassab and Ibrahim (2005), Boydak et al. (2007), El-Mahdi and El-Amin (2008), Jouyban and Moosavi (2012) and Khalil and El-Noemani (2012).

Table (3): Effect of irrigation intervals, compost, inoculation and their interactions on plant height, height of first capsule and fruiting zone length of sesame plants grown in sandy soil (2011 and 2012 seasons and their combination)

\begin{tabular}{|c|c|c|c|c|c|c|c|c|c|}
\hline \multirow{2}{*}{ Treatments } & \multicolumn{3}{|c|}{$\begin{array}{l}\text { Plant height } \\
\text { (cm) }\end{array}$} & \multicolumn{3}{|c|}{$\begin{array}{l}\text { Height of first capsule } \\
(\mathbf{c m})\end{array}$} & \multicolumn{3}{|c|}{$\begin{array}{l}\text { Fruiting zone length } \\
\text { (cm) }\end{array}$} \\
\hline & 2011 & 2012 & Comb. & 2011 & 2012 & Comb. & 2011 & 2012 & Comb. \\
\hline \multicolumn{10}{|l|}{ Irrigation intervals } \\
\hline$(\mathrm{I}):$ & 134.1 & 132.1 & 133.1 & 60.3 & 60.3 & 60.3 & 73.9 & 71.8 & 72.9 \\
\hline 6 days & 127.4 & 120.0 & 123.7 & 58.3 & 57.2 & 57.8 & 69.1 & 62.8 & 66.0 \\
\hline 9 days & 98.3 & 97.0 & 97.7 & 47.9 & 45.3 & 46.6 & 50.4 & 51.7 & 51.1 \\
\hline 12 days & $\star *$ & $\star *$ & ** & $\star \star$ & $\star \star *$ & $* \star$ & $* *$ & $* *$ & $* *$ \\
\hline $\begin{array}{l}\text { F-test } \\
\text { L.S.D at } 5 \%\end{array}$ & 4.369 & 4.239 & 2.530 & 5.845 & 6.064 & 3.601 & 7.040 & 2.702 & 3.034 \\
\hline \multicolumn{10}{|l|}{ Compost rates ( $\mathrm{C}$ ): } \\
\hline Zero (without compost) & 119.0 & 113.4 & 116.2 & 52.6 & 51.8 & 52.2 & 61.0 & 59.2 & 60.1 \\
\hline 5 ton/fed & 118.6 & 115.8 & 117.2 & 56.4 & 54.3 & 55.4 & 66.4 & 61.6 & 64.0 \\
\hline 7 ton/fed & 122.4 & 119.8 & 121.1 & 57.6 & 56.6 & 57.1 & 66.1 & 65.5 & 65.8 \\
\hline F-test & N.S & N.S & * & $* *$ & * & * & ** & * & $\star *$ \\
\hline L.S.D at $5 \%$ & - & - & 3.571 & 2.732 & 1.229 & 3.503 & 3.028 & 5.358 & 2.914 \\
\hline \multicolumn{10}{|c|}{ Bacterial inoculation } \\
\hline (B): & 118.0 & 114.1 & 116.1 & 52.2 & 53.6 & 52.9 & 59.2 & 59.2 & 59.2 \\
\hline Uninoculated & 122.0 & 118.7 & 120.3 & 58.9 & 54.9 & 56.9 & 69.9 & 65.1 & 67.5 \\
\hline Inoculated & N.S & N.S & * & ** & * & * & ** & ** & $* *$ \\
\hline $\begin{array}{l}\text { F-test } \\
\text { L.S.D at } 5 \%\end{array}$ & - & - & 3.252 & 4.600 & 1.014 & 3.396 & 3.951 & 3.708 & 3.206 \\
\hline \multicolumn{10}{|l|}{ Interactions : } \\
\hline $1 \times C$ & N.S & N.S & * & * & * & * & * & * & * \\
\hline $1 \times B$ & N.S & N.S & N.S & * & * & * & * & * & * \\
\hline$C \times B$ & N.S & N.S & N.S & * & N.S & N.S & * & * & * \\
\hline$I \times C \times B$ & N.S & N.S & N.S & * & N.S & N.S & * & * & * \\
\hline
\end{tabular}

* Inoculated= inoculation with mixture of Serratia sp., Bacillus polymyxa and Pseudomonas fluorescens

\section{b. Effect of compost:}

In respect to main effect of compost manuring on plant height, height of first capsule and fruiting zone length of sesame, data in Table (3) exerts that the rate of promotion in the studied sesame yield characters increased as the rate of compost manuring increased. It is realized that raising the rate of compost from zero to 7 ton/fed induced significant increases in plant height from 116.2 to $121.1 \mathrm{~cm}$, height of first capsule from 52.2 to $57.1 \mathrm{~cm}$ and fruiting zone length from 60.1 to $65.8 \mathrm{~cm}$. This distinct response to compost 
addition clearly reflected its essential role in establishment of fertile media for growing sesame plants leading to healthy vegetative growth, increase nutrients availability, either that its contain or those added as fertilizer and consequently sustain these plants to give high quality and quantity of sesame yield. The prominent role of organic materials in enhancing crops productivity was proved by many investigators (Abdel-Wahab et al., 2009; Pornparn et al., 2009 and El-Saiid, 2011).

\section{c. Effect of bacterial inoculation:}

Data in Table (3) indicate that the height of first capsule and fruiting zone length affected significantly by bacterial inoculation, while plant height insignificantly responded. This trend was true in both investigated seasons. Data of the combined two seasons responded ons revealed that triple inoculation with Serratia, Bacillus and Pseudomonas exerted a salient superiority in values of plant height $(120.3 \mathrm{~cm})$, height of first capsule $(56.9 \mathrm{~cm})$ and fruiting zone length $(67.5 \mathrm{~cm})$ relative to uninoculated treatment. These increases in such yield parameters as a function of rhizobacterial inoculation may explain their prominent roles in improvement of $\mathrm{N}_{2}$-fixation performance and nutrient status, these development responses occurred in the physiological processes of sesame plants mostly originated from several modes of action induced by such PGPRs. These modes of actions may include the production of phytohormones and siderophores (ferric-specific ligands), phosphate solubilization and increasing of root proliferation lead to generate a highly strength plants, consequently enhancing the yield produced from inoculated plants (Vessey, 2003; Hewedy et al., 2008; Verma et al., 2010 and Badawi et al., 2011).

2. Effect of irrigation intervals, compost and bacterial inoculation on number of capsules/plant, 1000 -seed weight and seed yield/plant of sesame plants:

a. Effect of irrigation intervals:

Irrigation of sesame plants with the three studied irrigation intervals (6, 9 and 12 days) showed significant effect on number of capsules/plant, 1000 -seed weight $(\mathrm{g})$ and seed yield/plant $(\mathrm{g})$ in both growing seasons and their combination (Table 4). However, increasing the severity and duration of drought all above tested yield attributes showed significant reduction. So, the sixth days irrigation interval produced the highest capsule number/plant (73.7), which was 18.87 and $55.81 \%$ greater than that at irrigation intervals of 9 and 12 days, respectively. It can be related to the decrease in photosynthesis potential and the resulting decrease in plant height as well as in auxiliary branch number and partly to the fall of flowers under water deficit stress. Similarly, it is observed that water stress adversely affected the growth and the number of capsules per plant in this study and in that reported by Rezvani et al. (2005), El-Mahdi and El-Amin (2008) and Jouyban and Moosavi (2012) who confirmed that the reduction in number of capsules per plant could be due to the effect of water stress during the reproductive phase. 
Table (4): Effect of irrigation intervals, compost, inoculation and their interactions on number of capsules/plant, 1000-seed weight and seed yield/plant of sesame plants grown in sandy soil (2011 and 2012 seasons and their combination)

\begin{tabular}{|c|c|c|c|c|c|c|c|c|c|}
\hline \multirow{2}{*}{$\begin{array}{l}\text { Characters } \\
\text { Treatments }\end{array}$} & \multicolumn{3}{|c|}{ No. of capsules/plant } & \multicolumn{3}{|c|}{1000 -seed weight $(\mathrm{g})$} & \multicolumn{3}{|c|}{ Seed yield/plant (g) } \\
\hline & \begin{tabular}{|l|}
2011 \\
\end{tabular} & 2012 & Comb. & 2011 & 2012 & Comb. & 2011 & 2012 & Comb. \\
\hline \multicolumn{10}{|l|}{ Irrigation intervals (I): } \\
\hline 6 days & 76.3 & 71.0 & 73.7 & 4.18 & 4.24 & 4.21 & 21.5 & 18.3 & 19.9 \\
\hline 9 days & 66.7 & 57.3 & 62.0 & 4.05 & 4.03 & 4.04 & 16.1 & 15.2 & 15.7 \\
\hline 12 days & 52.3 & 42.3 & 47.3 & 3.99 & 4.04 & 4.02 & 12.8 & 12.6 & 12.7 \\
\hline F-test & ** &  & $* *$ & $*$ & $*$ & * & $\star * *$ & $\star \star \star *$ & $* *$ \\
\hline L.S.D at $5 \%$ & 5.064 & 5.765 & 3.190 & 0.109 & 0.180 & 0.161 & 0.507 & 0.700 & 0359 \\
\hline \multicolumn{10}{|l|}{ Compost rates ( C): } \\
\hline Zero (without compost) & 39.0 & 30.4 & 34.7 & 3.89 & 3.98 & 3.94 & 9.9 & 9.9 & 9.9 \\
\hline 5 ton/fed & 74.5 & 56.4 & 65.5 & 4.17 & 4.17 & 4.17 & 18.6 & 16.0 & 17.3 \\
\hline 7 ton/fed & 80.5 & 83.7 & 82.1 & 4.16 & 4.14 & 4.15 & 21.9 & 20.1 & 21.0 \\
\hline F-test & $* *$ & $* *$ & $* *$ & $* *$ & $*$ & $* *$ & $* *$ & $* *$ & $* *$ \\
\hline L.S.D at $5 \%$ & 4.775 & 3.454 & 2.791 & 0.123 & 0.118 & 0.104 & 0.481 & 1.114 & 0.575 \\
\hline \multicolumn{10}{|l|}{ Bacterial inoculation } \\
\hline (B): & 50.3 & 50.4 & 50.4 & 3.95 & 3.98 & 3.97 & 15.1 & 14.1 & 14.6 \\
\hline Uninoculated & 79.2 & 63.3 & 71.3 & 4.20 & 4.22 & 4.21 & 18.5 & 16.6 & 17.6 \\
\hline Inoculated & ** & ** & ** & ** & ** & ** & ** & ** & ** \\
\hline $\begin{array}{l}\text { F-test } \\
\text { L.S.D at } 5 \%\end{array}$ & 5.376 & 3.650 & 3.139 & 0.105 & 0.130 & 0.081 & 0.433 & 0.680 & 0.389 \\
\hline Interactions : & & & & & & & & & \\
\hline $1 \times C$ & ** & ** & ** & N.S & N.S & * & ** & ** & ** \\
\hline $1 \times B$ & * & $*$ & 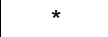 & N.S & N.S & * & * & ** & ** \\
\hline$C \times B$ & ** & ** & ** & N.S & N.S & * & ** & ** & ** \\
\hline $\mathrm{I} \times \mathrm{C} \times \mathrm{B}$ & * & * & * & N.S & N.S & N.S & ** & ** & ** \\
\hline
\end{tabular}

The variation on 1000-seed weight (Table 4) under different irrigation intervals was slight and it seems that this yield component is highly inheritable and is less affected by environmental factors. These results were fortified by those of Bashiri et al. (2010) and Jouyban and Moosavi (2012) who reported that there was a slight significant difference in 1000-seed weight under different irrigation intervals. On the other hand, significant higher values of seed yield/plant were recorded with the shortest irrigation intervals ( 6 days) followed by ( 9 days). The 6 day irrigation regime gave the maximum seed yield/plant (19.9 g) which was 26.75 and $56.69 \%$ greater than that under irrigation intervals of 9 and 12 days, respectively (Table 4). Numerous studies were indicated that seed yield can be drastically reduced as a result of water deficit during there productive period (Rezvani et al., 2005; Boydak et al., 2007 and Jouyban and Moosavi, 2012).

\section{b. Effect of compost:}

Data in Table (4) indicate that addition of compost resulted in significant increases in number of capsules/plant, 1000-seed weight and seed yield/plant as compared to unamended treatment, with salient superiority for using 7 ton compost/fed. Increasing application rate of compost from zero up to 7 ton/fed increased number of capsules/ plant from 34.7 to $82.1,1000$ seed weight from 3.94 to $4.15 \mathrm{~g}$ and seed yield/plant from 9.9 to $21.0 \mathrm{~g}$. These findings reflected the essential role of the distinct organic materials in 
improvement of sesame productivity in sandy soil, which might be elucidated by improving soil fertility and plant nutritional status leading to support plant growth and its natural healthy. The synergistic effect of bio-organic fertilization on crop productivity in newly reclaimed soils was confirmed by many workers (Abdel-Wahab et al., 2006 and Pornparn et al., 2009). Recently, Shaban et al. (2012) showed that the application of compost increased significantly sesame yield and its components, i.e. number of capsules/plant, seed weight/plant, and weight of 1000 -seeds.

\section{c. Effect of bacterial inoculation:}

Data presented in Table (4) indicate that the uninoculated plants gave the lowest values of capsules number/plant (50.4); 1000-seed weight $(3.97 \mathrm{~g})$ and seed yield/plant $(14.6 \mathrm{~g})$. However, the splendid significant effect was observed with the use of inoculation approach (mixture of Serratia, Bacillus and Pseudomonas) in relative to uninoculated ones. The corresponding increases in number of capsules/plant, 1000-seed weight and seed yield/plant were $41.47,6.05$ and $20.55 \%$, respectively, over the uninoculated treatment. These results clearly indicated the promotive effects of PGPRs on the productivity and quality of sesame plants grown in sandy soils. These dramatic effects of PGPRs may be originated as an end result of the boosting growth and nitrogen fixation performance as well as $P$ mobilization, phytohormone production and saving the bio-protection against phytopathogens (Dobbelaere et al., 2003; Vessey, 2003; Hewedy et al., 2008 and Verma et al., 2010).

3. Effect of irrigation intervals, compost and bacterial inoculation on seed yield/fed, oil percentage and oil yield/fed of sesame plants:

\section{a. Effect of irrigation intervals:}

Results in Table (5) indicate that all studied yield characters were significantly affected by the duration of irrigation intervals. It is clear that water stress negatively affected all yield characters (seed yield/fed, oil percentage and oil yield/fed) and the higher the level of water stress the greater the negative effect. This trend was true in both growing seasons and their combined. The 6 day irrigation regime gave the highest seed yield (529.3 $\mathrm{kg} / \mathrm{fed})$, oil percentage $(57.49 \%)$ and oil yield $(305.2 \mathrm{~kg} / \mathrm{fed})$, which was 32.62 and $46.78 \% ; 1.69$ and $2.94 \% ; 21.49$ and $50.79 \%$ greater than that at irrigation intervals of 9 and 12 days, respectively. These results were suggested that moisture deficiency induces various physiological and metabolic responses like stomatal closure, decline in growth rate and photosynthesis and ultimately the seed and oil yields (Flexas and Medrano, 2002 and El-Mahdi and El-Amin, 2008). So, the availability of water provides optimum ground for plant vegetative growth and increases plant photosynthesis area, assimilate production, capsule number/plant and seed number/capsule and finally, significantly increases both seed and oil yields. Confirmed results were obtained by Boydak et al. (2007), Karaaslan et al. (2007) and Aliabadi et al. (2009) who found that the seed and oil yields was reduced under water deficit stress as a result of longer irrigation intervals 
(extending the irrigation interval from 6 to 18 and 24 days). More recently, Jouyban and Moosavi (2012) confirmed that the irrigation interval of 6 days produced the highest seed and oil yields. They added that the decrease in irrigation interval increased sesame vegetative growth and photosynthesis capacity and as a result, its capsule number/plant, seed production potential, yield components and eventually, its biological yield.

Table (5): Effect of irrigation intervals, compost, inoculation and their interactions on seed yield/fed, oil percentage and oil yield/fed of sesame plants grown in sandy soil (2011 and 2012 seasons and their combination)

\begin{tabular}{|c|c|c|c|c|c|c|c|c|c|}
\hline \multirow{2}{*}{$\begin{array}{l}\text { Characters } \\
\text { Treatments }\end{array}$} & \multicolumn{3}{|c|}{ Seed yield $(\mathrm{kg} / \mathrm{fed})$} & \multicolumn{3}{|c|}{ Oil \% } & \multicolumn{3}{|c|}{ Oil yield $(\mathrm{kg} / \mathrm{fed})$} \\
\hline & 2011 & 2012 & Comb. & 2011 & 2012 & Comb. & 2011 & 2012 & Comb. \\
\hline \multicolumn{10}{|l|}{\begin{tabular}{|l|} 
Irrigation intervals \\
\end{tabular}} \\
\hline (I): & 556.4 & 502.1 & 529.3 & 57.47 & 57.50 & 57.49 & 320.8 & 289.6 & 305.2 \\
\hline 6 days & 376.3 & 421.8 & 399.1 & 56.43 & 56.62 & 56.53 & 263.0 & 239.3 & 251.2 \\
\hline $\begin{array}{l}9 \text { days } \\
12 \text { days }\end{array}$ & $\underset{* *}{376.6}$ & $\underset{* *}{344.6}$ & $\underset{\star \star}{360.6}$ & 55.70 & $\underset{* *}{56.00}$ & $\underset{* *}{55.85}$ & 210.8 & 194.0 & 202.4 \\
\hline $\begin{array}{l}\text { F-test } \\
\text { L.S.D at 5\% }\end{array}$ & 18.610 & 24.833 & 12.900 & 0.713 & 0.630 & 0.395 & 14.709 & 15.635 & 8.923 \\
\hline \multicolumn{10}{|l|}{ Compost rates ( C): } \\
\hline (without & 289.8 & 270.5 & 280.2 & 55.52 & 55.77 & 55.65 & 161.1 & 151.1 & 156.1 \\
\hline compost) & 435.1 & 442.2 & 438.7 & 56.80 & 56.85 & 56.83 & 298.1 & 251.7 & 274.9 \\
\hline $\begin{array}{l}5 \text { ton/fed } \\
7 \text { ton/fed }\end{array}$ & $\underset{* \star}{584.6}$ & $\underset{* *}{555.7}$ & 570.2 & 57.27 & 57.50 & 57.39 & 335.3 & 320.1 & $\underset{* *}{327.7}$ \\
\hline $\begin{array}{l}\text { F-test } \\
\text { L.S.D at } 5 \%\end{array}$ & 15.077 & 33.569 & 17.428 & 0.461 & 0.649 & 0.377 & 6.205 & 20.338 & 10.071 \\
\hline \multicolumn{10}{|l|}{ Bacterial } \\
\hline inoculation (B): & 381.5 & 386.1 & 383.8 & 56.56 & 56.80 & 56.68 & 229.8 & 220.3 & 225.1 \\
\hline Uninoculated & 491.5 & 459.5 & 475.5 & 56.50 & 56.61 & 56.56 & 299.9 & 261.6 & 280.8 \\
\hline Inoculated & $\star \star$ & ** & 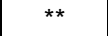 & N.S & N.S & N.S & ** & ** & ** \\
\hline $\begin{array}{l}\text { F-test } \\
\text { L.S.D at } 5 \%\end{array}$ & 10.268 & 18.151 & 10.074 & & & & 5.901 & 13.069 & 6.927 \\
\hline \multicolumn{10}{|l|}{ Interactions : } \\
\hline $\mathrm{I} \times \mathrm{C}$ & ** & ** & ** & * & N.S & * & ** & ** & ** \\
\hline $1 \times B$ & ** & ** & ** & N.S & N.S & ‡ & ** & ** & ** \\
\hline$C \times B$ & ** & ** & ** & N.S & N.S & N.S & ** & ** & ** \\
\hline $1 \times C \times B$ & ** & ** & ** & N.S & N.S & N.S & * & ** & ** \\
\hline
\end{tabular}

\section{b. Effect of compost:}

Data in Table (5) indicate that increasing the rate of compost manure induced significant increases in seed yield, seed oil percentage and oil yield and the promotion aspects increased gradually as the rate of compost increased. It is evident that sesame yield achieved the highest productivity as a result of soil manuring with 7 ton compost/fed followed 5 ton compost/fed. Topdressing sandy soil with compost at rates of 5 and 7 ton/fed increased significantly seed yield (kg/fed) by 56.57 and $103.49 \%$; seed oil percentage by 2.12 and $3.13 \%$ and oil yield $(\mathrm{kg} / \mathrm{fed}$ ) by 76.11 and $109.93 \%$ over the unamended treatment, respectively. The promotive effect of organic materials could be triggered as an end result of improvement of the sandy soil quality through affecting its physical, chemical and biological features. Thus, the 
organic fertilization is very essential in newly reclaimed soils to establish their biological activity and fertility. Similar tendency was obtained by Piqueres et al. (2006), Abdel-Wahab (2008), Pornparn et al. (2009), El-Saiid (2011) and Shaban et al. (2012).

c. Effect of bacterial inoculation:

Data in Table (5) indicate that sesame seed yield $(\mathrm{kg} / \mathrm{fed})$ and oil yield $(\mathrm{kg} / \mathrm{fed})$ were significantly affected by the bacterial inoculation, while oil percentage was insignificantly responded. The promotive effect on such yield characters was clear in presence of seed bacterization with mixture of tested rhizobacteria (PGPRs) than uninoculated one. This trend was true in both investigated seasons and their combined. The increments in yield characters due to biofertilization treatment were 23.89 and $24.74 \%$ for seed and oil yields, respectively. The beneficial effects of rhizobacterial inoculation (PGPR's) on enhancing the sesame yield characters may be elucidated by well habitation of these effective rhizobacteria in sesame rhizosphere and consequently they can promote the plant growth and yield via several mode of actions, which enhanced the nutrients availability and their uptake. Many other studies have confirmed positive effects of rhizobacterial inoculation on the growth and yield of different crops (Dobbelaere et al., 2003; Kloepper, 2003; Hewedy et al., 2008; Verma et al., 2010; Badawi et al. 2011 and Boghdady et al., 2012).

\section{Effect of the interactions on sesame yield and its attributes :}

Results in Tables (3,4 and 5) ratifies that the interaction effect among irrigation water intervals, compost rates and bacterial inoculation were positively significant on all estimated traits in both seasons and their combination except for plant height, height of first capsule, 1000-seed weight and oil percentage. At irrigation water intervals (6 days) in combination with 7 ton compost/fed and rhizobacterial inoculation gave the highest values of all studied characters compared to all other treatments in both seasons and their combined. Such results came in accordance with those presented by ElEgami (2004) and Abdel-Wahab (2008) who found that addition of compost and PGPRs led to pronounce the plant growth and productivity in sandy soils.

\section{Yield analysis:}

\section{Correlation studies:}

The results of simple correlation coefficients between oil yield $(\mathrm{kg} / \mathrm{fed})$ and other characters of sesame are presented in Table (6). Oil yield/fed was positively and highly correlated with fruiting zone length, number of capsules/plant, seed yield/plant, 1000-seed weight, seed yield/fed and oil\%. Ismail and Abd El-Nabi (2006), recorded same founding's. Also, plant height gave positive and highly significant correlation with height of first capsule, fruiting zone length, number of capsules/plant, seed yield/plant and oil\%. 
Table (6): Simple correlation coefficient between oil yield $(\mathrm{kg} / \mathrm{fed})$ and other characters of sesame (combined data)

\begin{tabular}{|c|c|c|c|c|c|c|c|c|}
\hline Characters & 1 & 2 & 3 & 4 & 5 & 6 & 7 & 8 \\
\hline YOil yield/fed $(\mathrm{kg})$ : & 0.5398 & 0.1382 & $0.7067^{* \star}$ & $0.9615^{\star \star}$ & $0.9954^{* *}$ & $0.8297^{\star \star}$ & $0.7021^{* *}$ & $0.8387^{* *}$ \\
\hline 1 Plant height & - & $0.8112^{\star *}$ & $0.9089^{\star \star}$ & $0.5545^{\star \star}$ & $0.5576^{*}$ & 0.4497 & 0.5217 & $0.6470^{*}$ \\
\hline 2Height first capsule & & - & 0.4936 & 0.2018 & 0.1728 & -0.0425 & 0.1920 & 0.4317 \\
\hline \begin{tabular}{|l|l|} 
Fruiting zone length \\
\end{tabular} & & & 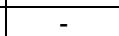 & $0.6923^{\star \star}$ & $0.7087^{\star *}$ & $0.7000^{\star \star}$ & $0.6412^{\star}$ & $0.6569^{*}$ \\
\hline 4 No of capsules/plant & & & & - & $0.9620^{* *}$ & $0.7909^{\star \star}$ & $0.9214^{\star \star}$ & $0.7510^{* *}$ \\
\hline 5 Seed yield /plant & & & & & - & $0.8070^{\star \star}$ & $0.9574^{\star \star}$ & -0.0595 \\
\hline $7 \mid 1000$-seed weight & & & & & & - & $0.8025^{\star \star}$ & $0.5828^{\star}$ \\
\hline 7 Seed yield/ feddan & & & & & & & - & $0.8310^{\star \star}$ \\
\hline 8 Oil \% & & & & & & & & \\
\hline
\end{tabular}

At the same time, close associations were found between fruiting zone length and each number of capsules/plant, seed yield/plant, 1000-seed weight, seed yield/fed and oil \%. Similar correlations reported by AbdelHakem and Abou-Salama (1995) \& Ismail and Abd El-Nabi (2006). Furthermore, seed yield/plant showed positive and highly significant correlation with 1000-seed weight and seed yield/fed. Likewise, 1000-seed weight was positive and showed highly significant correlations with seed yield/fed and oil \%. Also, seed yield/fed gave positive and highly significant correlation only with oil\%. These results are agreement with those of Ismail and Abd El-Nabi (2006).

As a results of this study indicated that obtaining the highest sesame seed and oil yields/fed occurred when the crop was irrigated interval as narrow as possible up to 6 days interval along with inclusion of 7 ton compost/fed and rhizobacterial inoculation. This could be an effective approach for improving the yield quality of sesame in sandy soil under Egyptian conditions. However, these obtained results are in need to be repeated to reach the level of recommendation.

\section{REFERENCES}

Abdel-Hakem, Y. A. and A. M. Abou-Salama (1995). Effect of skip irrigation and fungicidal treatments on yield and qulity of sesame. Assiut. J. Agric. Sci., 26: 127-135.

Abdel-Wahab, A. F. M. (2008). Evaluation of enriched compost and its role in synergy with rhizobacteria and $n$-fertilization for improving maize productivity in sandy soil. Arab Univ. J. Agric. Sci., 16: 319-334.

Abdel-Wahab, A. F. M.; A. M. M. Biomy and W. M. El-Farghal (2009). Co-composting of plant residues and their utility with micronutrients to enhance productivity of faba bean-Rhizobium symbiosis under sandy soil conditions. Egypt J. Appl. Sci., 24: 343-368.

Abdel-Wahab, A. F. M., F. Sh. F. Badawi and A. A. Abo El- Soud (2005). Effect of bioorganic conditioner on growth and yield of corn and peanut cultivated in sandy soil. J. Agric. Sci. Mans. Univ., 30: 5579-5595.

Abdel-Wahab, A. F. M.; G. A. A. Mekhemar, Heba Sh. Shehata and A. A. Hanafi (2006). Effect of plant growth bioprotecting and promoting rhizopacteria and compost on the healthy and productivity of peanut crop in sandy soil. Minufia J. Agric. Res., 31:1323-1348. 
Aliabadi, F. H., S. A. R. Valadabadi, J. Daneshian and M. A. Khalvati (2009). Evaluation changing of essential oil of balm (Melissa officinalis L.) under water deficit stress conditions. J. Med. Plant. Res., 3: 329-33.

A.O.A.C. (1980). Association of Official Analytical Chemists, Official Methods of Analysis. $16^{\text {th }} \mathrm{Ed}$. AOAC. International. Washington, DC, USA.

Atlas, R. M. (1995). Handbook of Media for Environmental Microbiology. pp. 562. CRC Press, Boca Raton, Florida, USA.

Badawi, F. Sh. F., A. M. M. Biomy and and A. H. Desoky (2011). Peaunt plant growth and yield as influenced by co-inoculation with Bradyrhizobium and some rhizo-microorganims under sandy loam soil conditions. Annals Agric. Sci., Fac. Agric., Ain Shams Univ., 56: 1-9.

Bashiri, S., A. Sepehri, M. A. Abootalebian and M. M. Ghasemi (2010). Effect of nitrogen and sulfur on yield and yield components of rape under water deficit stress. Proc. $10^{\text {th }}$ Iranian Agric. Plant Breeding Conf., Environ. Res., Center, Shahid Beheshti Univ., Tehran, Iran.

Boghdady, M. S., Rania M. A. Nassar and F. A. Ahmed (2012). Response of sesame plant (Sesamum orientale L.) to treatments with mineral and bio-fertilizers. Res. J. Agric. Biol. Sci., 8: 127-137.

Boydak, E., D. Karaaslan, M. Simsek and S. Gercek (2007). Effect of irrigation methods and irrigation intervals on yield and some yield components of sesame growing in semi-arid area. J. Agron., 6: 439443.

Cotxarrera, L., M. L. Trillas-Gay, C. Steinberg and C. Alabouvette (2002). Use of sewage sludge compost and Trichoderma asperellum isolates to suppress Fusarium wilt of tomato. Soil Biol. Biochem., 34: 467-476.

Dobbelaere, S., J. Vanderleyden and Y. Okon (2003). Plant growth promoting effects of diazotrophs in the rhizosphere. Crit. Rev. Plant Sci., 22: 107149.

El-Egami Hend, M.A. (2004). Studies on nitrogen fixers as plant growth promoting rhizobacteria in legumes and non-legumes. M.Sc. Thesis, Fac. Agric., Cairo Univ., Egypt.

El-Mahdi,A. A. and S. M. El-Amin (2008). Effect of irrigation intervals on growth and yield of sesame (Sesmum indicum. L) in Northern Suban. Assiut. J. Agric. Sci., 39: 1-9.

El-Saiid, G. A. E. (2011). The role of enriched compost and rhizobacteria in achievement of the integrated fertilization management concept. M.Sc. Thesis, Fac. Agric., Ain Shams Univ., Egypt.

Flexas, J. and H. Medrano (2002). Drought-inhibition of photosynthesis in C3 plants: stomatal and non-stomatal limitations revisited. Ann. Bot., 89: 183-189.

Ghosh, D. C. and M. D. Mohiuddin (2000). Respones of summer sesame (Sesmum indicum. L) to biofertilizer and growth regulator. Agric. Sci., 20: 90-92.

Gomez, K. A. and A. A. Gomez (1984). Statistical Procedures for Agriculture Research. A Wiley. Inter Science Publication. John Wiley \& Sons, Inc. New York, USA.

Gosling, P., A. Hodge, G. Goodlass and G. D. Bending (2006). Arbuscular mycorrhizal fungi and organic farming. Ecosyst. Environ., 113: 17-35. 
Hewedy Maha, A., A. F. Abdel-Wahab, El-Mokadem M. T. and S. Y. El-Sayed (2008). The effectively of plant growth promoting rhizobacteria to enhance growth of lupine and chickpea. New Egypt. J. Microbiol., 21: 235-252.

Ismail, F. M. and Heba M. Abd El-Nabi (2006). Effect of some antioxidants on the incidence of damping- off, root rot, wilt, yield and yield attributes in sesame (Sesmum indicum. L). J. Agric. Sci. Mans. Univ., 31: 6155 6171.

Jackson, M. L. (1973). "Soil Chemical Analysis". pp. 122-128. Prentice. Hall of India Private Limited, New Delhi, India.

Jouyban, Z. and S. G. Moosavi (2012). Effect of different irrigation intervals, nitrogen and superabsorbent levels on chlorophyll index, yield and yield components of sesame. J. Food Agric. Environ., 10: 360-364.

Karaaslan, D., E. Boydak, S. Gercek and M. Simsek (2007). Influence of irrigation intervals and row spacing on some yield components of sesame grown in Harran Region. Asian J. Plant Sci., 6: 623-627.

Kassab, O. M. and M. M. Ibrahim (2005). Effect of skipping one irrigation at vegetative or flowering growth stages and foliar application of potassium on growth and yield of sesame. J. Agric. Res., Tanta Univ., 31: 222-231.

Khalil Soha, E. and A. A. El-Noemani (2012). Effect of irrigation intervals and exogenous proline application in improving tolerance of garden cress plant (Lepidium sativum L.) to water stress. J. Appl. Sci. Res., 8: 157167.

Kloepper, J. W. (2003). A review of mechanisms for plant growth promotion by PGPR. 6th International PGPR Workshop, pp. 15-23, 6-10 October 2003, Calcutta, India.

Mantelin, S. and B. Touraine (2004). Plant growth promoting bacteria and nitrate availability: impacts on root development and nitrate uptake. $\mathrm{J}$. Exp. Bot., 55: 27-34.

Mathew, T. and U. M. Kunju (1993). Influence of irrigation on growth and yield of Sesamum (C.F, Field Crop Abst), 48 (5): 3682, (1995).

Page, A. L., R. H. Miller and D. R. Keeney (1982). "Methods of Soil Analysis". II. Chemical and Microbiological Properties. $2^{\text {nd }}$ Ed. Madison, Wisconsin, USA.

Piqueres, A. P., V. Edel-Hermann, C. Alabouvette and C. Steinberg (2006). Response of soil microbiologilogy communities to compost amendments. Soil Biol. Biochem., 38: 460-470.

Pornparn, S., S. Suwannaketnikom, W. Dumkhum and N. Duadao (2009). Fertilizers for organic sesame. Asian. J. Food Agric. Ind., 197-204.

Rezvani, M. P., G. Norouzpour, J. Nabati and A. A. Mohammadabadi (2005). Effects of different irrigation intervals and plant density on morphological characteristics, grain and oil yields of sesame (Sesamum indicum). Iran. J. Field Crops Res., 3: 57-68.

Sabah El-Khier, M. K., K. A. Ishag and A. A. Yagoub (2008). Chemical composition and oil characteristics of sesame seed cultivars grown in Sudan. Research Journal of Agric. Biol. Sci., 4:761-766.

Shaban, Kh. A., Mona G. Abd El-Kader and Zeinab M. Khalil (2012). Effect of soil amendments on soil fertility and sesame crop productivity under newly reclaimed soil conditions. J. Appl. Sci. Res., 8: 1568-1575. 
Snedecor, G. W. and W. G. Chochran (1980). Statistical Methods, $7^{\text {th }}$ Ed. Pp. 255-269. lowa State University Press. Ames, USA.

Svab, J. (1973). Biometrical modszerek a Kutatasban Mezogazdasagi Kiado. Budapest. Hungary.

Van-Loon, L. C. and P. A. H. M. Bakker (2003). Signaling in rhizobacteriaplant interactions. Ecol. Stud., 68: 290-330.

Verma, J. P., J. Yadav, K. N. Tiwari and V. Singh (2010). Impact of plant growth promoting rhizobacteria on crop production. Int. J. Agric. Res., 5: 954-983.

Vessey, J. K. (2003). Plant growth promoting rhizobacteria as biofertilizers. Plant and Soil. 255:571-586.



كلية الزراعة - جامعة المنصورة

مركز البحوث الزراعية

\author{
قام بتحكيم البحث \\ أ. أد / فتحي اسماعيل على حوقه البح
}

أ.د / فكرى محمد عبد العال غزال 